\title{
Adapting Root Distribution and Improving Water Use Efficiency via Drip Irrigation in a Jujube (Zizyphus jujube Mill.) Orchard after Long-Term Flood Irrigation
}

\author{
Zhaoyang Li ${ }^{1,2}$, Rui Zong ${ }^{1}$, Tianyu Wang ${ }^{1}$, Zhenhua Wang ${ }^{1, *}$ and Jinzhu Zhang ${ }^{1}$ \\ 1 College of Water and Architectural Engineering, Shihezi University, Shihezi 832000, China; \\ lizhaoyang2i1@163.com (Z.L.); zongray@126.com (R.Z.); 15963100756@163.com (T.W.); xjshzzjz@sina.cn (J.Z.) \\ 2 College of Water Conservancy and Architecture Engineering, Tarim University, Alaer 843300, China \\ * Correspondence: wzh2002027@shzu.edu.cn
}

check for updates

Citation: Li, Z.; Zong, R.; Wang, T.; Wang, Z.; Zhang, J. Adapting Root Distribution and Improving Water Use Efficiency via Drip Irrigation in a Jujube (Zizyphus jujube Mill.) Orchard after Long-Term Flood Irrigation. Agriculture 2021, 11, 1184. https:// doi.org/10.3390/agriculture11121184

Academic Editor: Virginia

Hernandez-Santana

Received: 18 October 2021

Accepted: 22 November 2021

Published: 24 November 2021

Publisher's Note: MDPI stays neutral with regard to jurisdictional claims in published maps and institutional affiliations.

Copyright: (c) 2021 by the authors. Licensee MDPI, Basel, Switzerland. This article is an open access article distributed under the terms and conditions of the Creative Commons Attribution (CC BY) license (https:/ / creativecommons.org/licenses/by/ $4.0 /)$.

\begin{abstract}
Jujube tree yields in dryland saline soils are restricted by water shortages and soil salinity. Converting traditional flood irrigation to drip irrigation would solve water deficit and salt stress. The root distribution reacts primarily to the availability of water and nutrients. However, there is little information about the response of jujube roots to the change from flood irrigation to drip irrigation. In this context, a two-year experiment was carried out to reveal the effects of the change from long-term flood irrigation to drip irrigation on soil water, root distribution, fruit yield, and water use efficiency (WUE) of jujube trees. In this study, drip irrigation amounts were designed with three levels, i.e., $880 \mathrm{~mm}$ (W1), $660 \mathrm{~mm}$ (W2), $440 \mathrm{~mm}$ (W3), and the flood irrigation of $1100 \mathrm{~mm}$ was designed as the control (CK). The results showed that replacing flood irrigation with drip irrigation significantly altered soil water distribution and increased soil moisture in the topsoil $(0-40 \mathrm{~cm})$. In the drip irrigation treatments with high levels, soil water storage in the $0-60 \mathrm{~cm}$ soil layer at the flowering and fruit setting, and fruit swelling stages of jujube trees increased significantly compared with the flood irrigation. After two consecutive years of drip irrigation, the treatments with higher irrigation levels increased root length density (RLD) in 0-60 cm soil depth but decreased that in the 60-100 cm depth. In the horizontal direction, higher irrigation levels increased RLD in the distance of $0-50 \mathrm{~cm}$, while reducing RLD in the distance of 50-100 cm. However, the opposite conclusion was obtained in W3 treatment. Additionally, in the second year of drip irrigation, W2 treatment $(660 \mathrm{~mm})$ significantly improved yield and WUE, with an increasing of $7.6 \%$ for yield and $60.3 \%$ for WUE compared to the flood irrigation. In summary, converting flood irrigation to drip irrigation is useful in regulating root distribution and improving WUE, which would be a promising method in jujube cultivation in arid regions.
\end{abstract}

Keywords: drip irrigation; root length density; jujube tree; soil moisture; water use efficiency

\section{Introduction}

Jujube cultivation originated in China and has been continued for more than 4000 years [1] It is mainly cultivated in Shandong, Hebei, Shanxi, Shaanxi, Henan provinces and Xinjiang Uygur Autonomous Region in China. Among them, Xinjiang has become the largest jujube producing area in China due to its special climatic environments [2,3]. Xinjiang is an arid area with a shortage of water resources, most crops in this area have been planted with advanced drip irrigation technology [4]. However, most jujube trees are irrigated by traditional flood irrigation, which has low water use efficiency [5]. At the same time, long-term flood irrigation in arid areas can easily lead to soil compaction and secondary salinization, which results in reducing crop yields and soil quality [6,7]. Therefore, studying the impact of changes in irrigation methods on the water requirement and plant growth of jujube trees is of great significance for improving jujube yields and saving water resources in arid areas. 
Root activity and distribution are critical for plants to absorb water and nutrients, as well as synthesize various physiologically-active substances [8-10]. Environmental factors and agriculture management practices play important roles in root development [11]. For example, irrigation methods can regulate plant root development by changing soil water distribution and assimilate partitioning [12-14]. Drip irrigation decreased the redundancy growth of roots, which can effectively regulate root distribution [15-17]. In comparison to furrow irrigation, drip irrigation can significantly improve root development and yield of maize [18]. A previous study found that drip irrigation can significantly improve wheat root traits in the $0-30 \mathrm{~cm}$ soil layer when compared with conventional border irrigation [19]. Another study reported that low irrigation level decreased the maximum rooting depth of jujube, and reduced the use of deep soil water, which might be helpful to control secondary soil salinization [20]. Furthermore, compared to the micro-sprinkler irrigation methods, the root length of avocado trees under drip irrigation was increased by $30 \%$, and the number of apple tree roots was significantly changed, of which both factors are favorable for plant growth and yield improvement [21]. The characteristics of root distribution of fruit tree were easily influenced by irrigation methods and irrigation levels. However, the impact of the irrigation methods changing (drip irrigation instead of flood irrigation) on root redistribution in the arid region is still unknown.

As a perennial fruit tree, the development of jujube tree is easily influenced by climate factors, tree ages, and soil moisture and nutrient status. Roots of this tree were primarily distributed in the top $60 \mathrm{~cm}$ soil layer vertically and $60 \mathrm{~cm}$ horizontal distance from the trunk [22]. This tree absorbs water mainly from shallow layers, but deeper soil water also might be extracted to sustain growth when soil water in the topsoil could not meet the plant growth needs. Drip irrigation is a localized irrigation technology, which limits the scope of soil moisture distribution compared with flood irrigation, which might have negative effects on root growth of jujube tree beyond the wetting range. In recent years, the local government has tried to use drip irrigation instead of flood irrigation to irrigate the jujube orchards, but the root system of the jujube trees in the long-term flood irrigation has been adapted to the flood irrigation methods. Therefore, drip irrigation technology has not been widely promoted and applied. Despite a lot of experiments focused on the different irrigation methods on root distribution and water utilization in jujube orchard, there was little information about the adaptive response of jujube root development to changing soil water distribution [23-25]. We hypothesized that drip irrigation could reconstruct jujube root by contracting water distribution, and appropriate irrigation levels could increase jujube yield and water use efficiency. Therefore, the objectives of this study were (i) to investigate the effects of replacing long-term flood irrigation with drip irrigation on soil water and root redistribution of jujube, (ii) to measure the effects of irrigation amounts on perennial jujube yield and water use efficiency after conversion from flood irrigation to drip irrigation.

\section{Materials and Methods}

\subsection{Experimental Site}

The experiment was conducted in 2018-2019 at the Experimental Station $\left(81^{\circ} 13^{\prime} \mathrm{E}\right.$, $40^{\circ} 34^{\prime} \mathrm{N}$; altitude of $1015 \mathrm{~m}$ ) of the 10th Regiment of the First Division of the Xinjiang Production and Construction Corps. The study site is located on the northern edge of the Taklimakan Desert with a typical continental arid desert climate that is characterized by hot summers with low rainfall, cold winters with little snow, and strong surface evaporation. Based on Aksu Meteorological Station, over the past 30 years, the average annual rainfall and evapotranspiration were 50 and $2200 \mathrm{~mm}$, respectively. The annual sunshine duration in this region was observed $2556-2992 \mathrm{~h}$, the annual mean temperature was $8.4-11.4^{\circ} \mathrm{C}$, and the annual frost-free season recorded 180-221 days, respectively. The rainfall during the jujube growth period (April-October) in 2018 and 2019 was $41.6 \mathrm{~mm}$ and $61.2 \mathrm{~mm}$, respectively. The depth to the groundwater table was more than $3.5 \mathrm{~m}$. A weather station (HOBO U30; Onset, Bourne, MA, USA) was used to automatically monitor and record 
climatic variables. Figure 1 presents the maximum and minimum temperature (Tmax and Tmin), precipitation (P), and reference evapotranspiration (ETo) during the jujube growth period in 2018 and 2019. The basic properties of soil in the 0-100 cm layer are shown in Table 1.

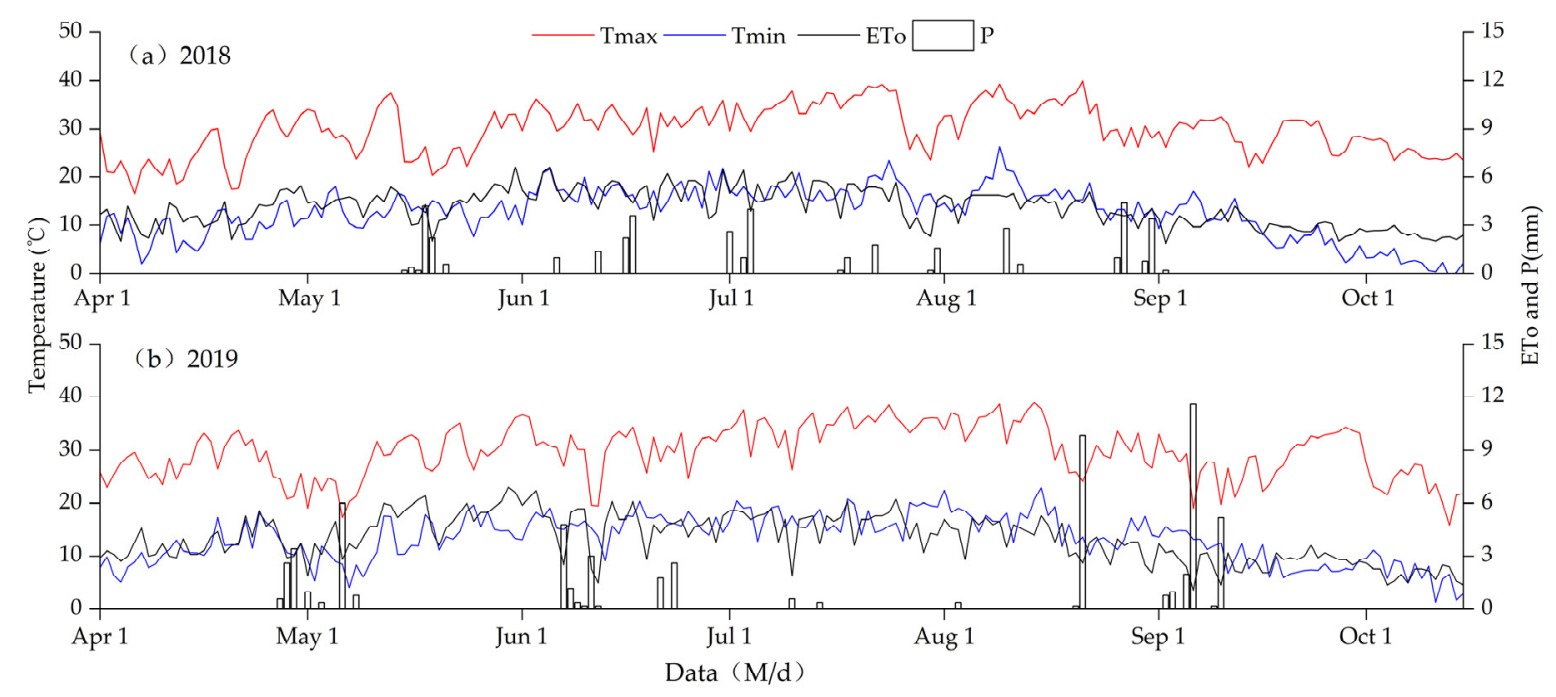

Figure 1. Maximum temperature (Tmax), minimum temperature (Tmin), reference crop evapotranspiration $\left(\mathrm{ET}_{0}\right)$, and precipitation (P) in (a) 2018 and (b) 2019.

Table 1. Basic physical and chemical properties of soil in the test field.

\begin{tabular}{|c|c|c|c|c|c|c|}
\hline $\begin{array}{l}\text { Soil Depth } \\
(\mathrm{cm})\end{array}$ & Soil Texture & $\begin{array}{c}\theta_{\mathrm{FC}} \\
\left(\mathrm{cm}^{3} \mathrm{~cm}^{-3}\right)\end{array}$ & $\begin{array}{c}\text { Soil Bulk } \\
\text { Density } \\
\left(\mathrm{g} \mathrm{cm}^{-3}\right)\end{array}$ & $\begin{array}{l}\text { Total Nitrogen } \\
\quad\left(\mathrm{g} \mathrm{kg}^{-1}\right)\end{array}$ & $\begin{array}{c}\text { Available } \\
\text { Phosphorus } \\
\left(\mathrm{mg} \mathrm{kg}^{-1}\right)\end{array}$ & $\begin{array}{l}\text { Available } \\
\text { Potassium } \\
\left(\mathrm{mg} \mathrm{kg}^{-1}\right)\end{array}$ \\
\hline $0-20$ & Sandy loam soil & 0.316 & 1.52 & 1.23 & 50.24 & 121.58 \\
\hline $20-40$ & Sandy loam soil & 0.342 & 1.53 & 1.27 & 48.37 & 109.38 \\
\hline $40-60$ & Sandy loam soil & 0.349 & 1.54 & 1.26 & 42.41 & 96.57 \\
\hline $60-80$ & Sandy soil & 0.322 & 1.57 & 0.94 & 36.32 & 87.72 \\
\hline 80-100 & Sandy soil & 0.319 & 1.57 & 0.67 & 28.71 & 63.21 \\
\hline
\end{tabular}

\subsection{Experimental Design and Field Management}

In this study, Jujube trees (Zizyphus jujube Mill.) were planted in 2007, grafted in 2008 , and cultivated for 11 years. The densely-planted orchard has a planting density of 6253 plants ha ${ }^{-1}$ with a row spacing of $2.0 \mathrm{~m}$ and plant spacing of $0.8 \mathrm{~m}$. From 2007 to 2017, the trees were cultivated with flood irrigation continuously. Since 2018, drip irrigation was adopted with two pipes per row. Drip line was placed at a distance of $0.2 \mathrm{~m}$ to the tree row on each side. A labyrinth thin-wall drip irrigation line with an inner diameter of $16 \mathrm{~mm}$ was used with an emitter spacing of $0.3 \mathrm{~m}$ and emitter discharge of $2.8 \mathrm{~L} \mathrm{~h}^{-1}$ in a system operating pressure of $0.1 \mathrm{MPa}$.

In order to find the optimized water management of jujube from traditional flood irrigation to drip irrigation, we comprehensively analyzed the local long-term drip irrigation amount (360-470 $\mathrm{mm}$ ) [26] and the traditional flood irrigation amount $(1100 \mathrm{~mm})$ during the growth period of jujube tree. Drip irrigation was conducted using three different amounts: $80 \%, 60 \%$, and $40 \%$ of the flood irrigation amounts, which translated to $880 \mathrm{~mm}$ (W1), $660 \mathrm{~mm}$ (W2), and $440 \mathrm{~mm}$ (W3). A flood irrigation treatment was used as a control group (CK). As a result, a total of four treatments with three replicates were conducted in 12 plots. A completely randomised block design was adopted for the experiment. Each test plot had an area of $48 \mathrm{~m}^{2}(8 \mathrm{~m} \times 6 \mathrm{~m})$, and a separate water gauge was installed on the pipeline to monitor and control the irrigation water volume. According to the characteristics of drip irrigation and the water requirement law of jujube [27], a total of 
12 times of irrigation were applied during the growth period. Specifically, irrigation was applied every 15 days during Germination and New shoot, which the first irrigation was in late May. During flowering and fruit setting, the irrigation frequency was once every 7 days, and during fruit swelling, the irrigation frequency was once every 10 days. Then, the last irrigation was applied during fruit ripening. The CK consisted of the local flood irrigation practice, which comprised of a total of six irrigation events during the growth period. Here, only one irrigation was applied during Germination and New shoot. During flowering, fruit setting and fruit swelling, the irrigation frequency was once every 20 days. Then, the last irrigation was applied during fruit ripening. Irrigation scheduling for drip irrigation and flood irrigation are shown in Table 2.

Table 2. Irrigation scheduling of jujube in 2018 and 2019.

\begin{tabular}{|c|c|c|c|c|c|c|c|}
\hline \multirow{2}{*}{ Year } & \multirow{2}{*}{ Growth Stage } & \multirow{2}{*}{ Period } & \multicolumn{4}{|c|}{ Irrigation Treatment (mm) } & \multirow{2}{*}{$\begin{array}{l}\text { Irrigation } \\
\text { Events } \\
\text { Drip/Flood }\end{array}$} \\
\hline & & & W1 & W2 & W3 & CK & \\
\hline \multirow{4}{*}{2018} & $\begin{array}{l}\text { Germination and } \\
\text { New shoot }\end{array}$ & $4 / 30-6 / 15$ & 146.7 & 110 & 73.3 & 183.3 & $2 / 1$ \\
\hline & $\begin{array}{l}\text { Flowering and } \\
\text { Fruit setting }\end{array}$ & $6 / 16-7 / 20$ & 366.6 & 275 & 183.3 & 366.7 & $5 / 2$ \\
\hline & Fruit swelling & $7 / 21-8 / 31$ & 293.4 & 220 & 146.7 & 366.7 & $4 / 2$ \\
\hline & Fruit ripening & $9 / 1-10 / 20$ & 73.3 & 55 & 36.7 & 183.3 & $1 / 1$ \\
\hline \multirow{4}{*}{2019} & $\begin{array}{l}\text { Germination and } \\
\text { New shoot }\end{array}$ & $5 / 3-6 / 20$ & 146.7 & 110 & 73.3 & 183.3 & $2 / 1$ \\
\hline & $\begin{array}{l}\text { Flowering and } \\
\text { Fruit setting }\end{array}$ & $6 / 21-7 / 23$ & 366.6 & 275 & 183.3 & 366.7 & $5 / 2$ \\
\hline & Fruit swelling & $7 / 24-9 / 3$ & 293.4 & 220 & 146.7 & 366.7 & $4 / 2$ \\
\hline & Fruit ripening & $9 / 4-10 / 25$ & 73.3 & 55 & 36.7 & 183.3 & $1 / 1$ \\
\hline
\end{tabular}

W1, W2, and W3 indicate the seasonal amounts of 880, 660, and $440 \mathrm{~mm}$ under drip irrigation. CK indicates the seasonal amount of $1100 \mathrm{~mm}$ under flood irrigation.

\subsection{Measurements}

\subsubsection{Soil Moisture}

Soil moisture content was measured using the oven drying method. Soil cores were sampled at the horizontal distances of $0,20,35,50,70$, and $100 \mathrm{~cm}$ from the jujube trunk in a direction perpendicular to the drip irrigation tape. At each sampling site, soil samples were collected every $20 \mathrm{~cm}$ in the $0-100 \mathrm{~cm}$ soil profile vertically. There were 30 soil samples in each plot at each sampling date. Sampling was conducted at $24 \mathrm{~h}$ after irrigation to determine soil water distribution. Additional sampling was carried out at the beginning and end of each growth stage to determine soil water storage (SWS, $\mathrm{mm}$ ). SWS is calculated as follows:

$$
S W S=\sum_{i=1}^{n}\left(s w c_{i} H_{i} \times 10\right)
$$

where $s w c_{i}(\%)$ is the volumetric moisture content in soil layer $i, H_{i}(\mathrm{~cm})$ is the depth of soil layer $i$, and $n$ is the number of soil layers.

Evapotranspiration $(E T, \mathrm{~mm})$ is calculated as follows:

$$
E T=I+P+K-C+\Delta S W S
$$

where $I(\mathrm{~mm})$ is the irrigation amount, $P(\mathrm{~mm})$ represents the rainfall, $K(\mathrm{~mm})$ denotes the upward capillary flow into the root zone, $C(\mathrm{~mm})$ the deep percolation, and $\Delta S W S$ is the soil water storage change in the soil profile of $0-100 \mathrm{~cm}$. Because of the groundwater table being more than $3.5 \mathrm{~m}$ and the low rate of drip irrigation as well as a clay layer in the soil layer more than $1 \mathrm{~m}$ underground in the test area, the present study ignored the groundwater supply and the volume of drained water, thereby $C=0$ and $K=0$. 
Water use efficiency (WUE, $\mathrm{kg} \mathrm{m}^{-3}$ ) is calculated as follows:

$$
W U E=Y / E T / 10
$$

where $Y\left(\mathrm{~kg} \mathrm{ha}^{-1}\right)$ is the jujube fruit yield. At harvesting, five jujube trees were randomly chosen from each plot to measure the jujube fruit dry weight (yield).

\subsubsection{Root Sampling}

Three jujube trees with uniform growth were selected in each experimental plot for root sampling. A sampling control area was established for each jujube tree using the following steps: (1) delineating an $80 \mathrm{~cm} \times 100 \mathrm{~cm}$ rectangle by placing the two short vertices $(80 \mathrm{~cm})$ at the centers between the test jujube plants and the adjacent plants in the same row; (2) delineating a circular radius of $100 \mathrm{~cm}$ centered at the sampling plant but confined in the rectangle. This radius was used to determine the sampling control area of the roots. Sampling was conducted at four points at horizontal distances of $0-25 \mathrm{~cm}, 25-50 \mathrm{~cm}, 50-75 \mathrm{~cm}$, and $75-100 \mathrm{~cm}$ from the plant within the sampling control area, respectively. To improve the accuracy of the data, spatial variability for jujube root distribution and different numbers of sampling were designed at different sites from the jujube tree in the horizontal direction, i.e., one sampling point at $0-25 \mathrm{~cm}$, two at $25-50 \mathrm{~cm}$, three at $50-75 \mathrm{~cm}$, and three at $75-100 \mathrm{~cm}$. At each sampling point, samples were collected every $20 \mathrm{~cm}$ within $0-100 \mathrm{~cm}$ depth (Figure 2).

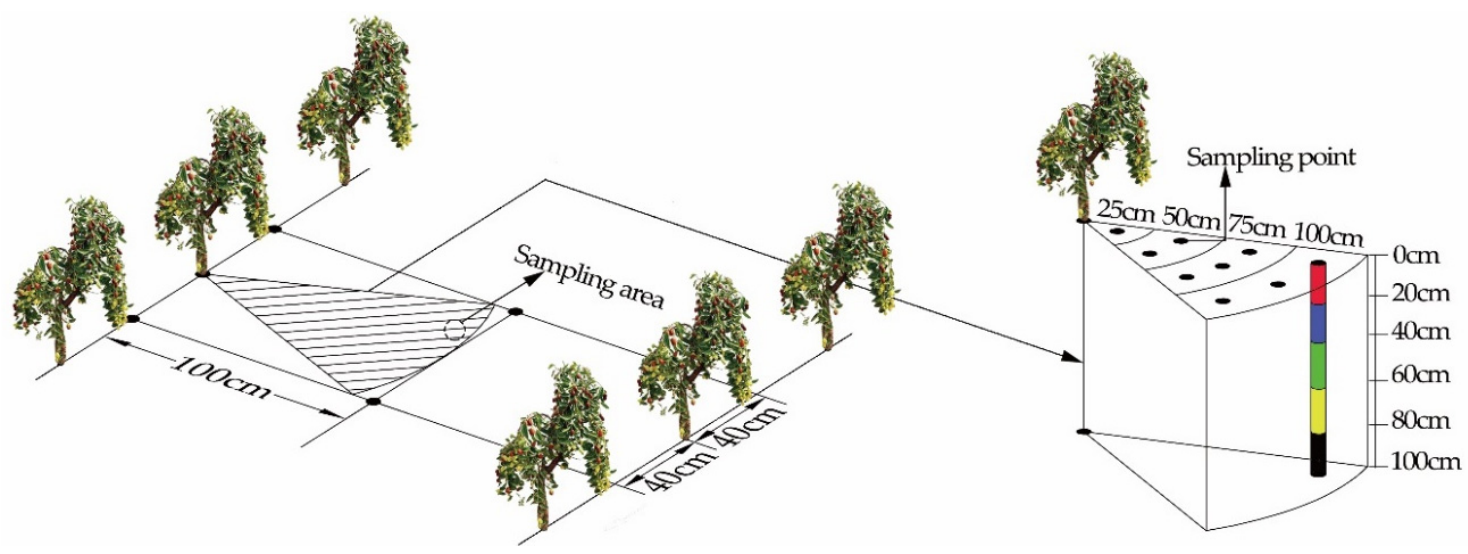

Figure 2. Schematic of root sampling.

Sampling was conducted at the end of the growth period (around mid-October every year) using a root drill with $10 \mathrm{~cm}$ in inner diameter and $20 \mathrm{~cm}$ in barrel length. The sampling was repeated three times. The residual roots, grass roots, and other impurities were removed from the samples, and then live jujube roots were harvested, rinsed clean and scanned using a root scanner to generate black-and-white JPG images for subsequent analysis. The images were analyzed using WinRHIZO (Professional version, Regent Instruments Inc. Quebec, Canada) image analysis software to obtain the root length of each sample. The root length density (RLD) was calculated by dividing the root length by the corresponding soil volume.

\subsection{Root Simulation}

A two-dimensional distribution model of jujube root under drip irrigation was developed. Based on the field data and previous studies, the roots distribution has the relation of negative exponential function with the vertical and horizontal distance varia- 
tion [28]. The two-dimensional model proposed by Vrugt et al. [29] could simulate crop root distribution well. The model was as following:

$$
R L D(z, r)=\left(1-\frac{z}{z_{m}}\right)\left(1-\frac{r}{r_{m}}\right) e^{-\left(\frac{p_{z}}{z_{m}}\left|z^{*}-z\right|+\frac{p_{r}}{r_{m}}\left|r^{*}-r\right|\right)}
$$

where $\operatorname{RLD}(z, r)$ is root long density $\left(\mathrm{m} \mathrm{m}^{-3}\right) ; r$ and $z$ are the horizontal and vertical distances, respectively, from the central point (Jujube tree) (m); $z_{m}$ and $r_{m}$ are the horizontal and vertical distances where the highest RLD was obtained $(\mathrm{m}) ; z^{*}$ and $r^{*}$ are the horizontal and vertical maximum extend distances of jujube tree $(\mathrm{m})$, respectively.

However, this model only simulated the root distribution located at different positions while the superposition of crop root was ignored. In this study, the jujube orchard with high density was irrigated for many years, and the plant spacing and row spacing were relatively low, which the root system inevitably has different degrees of superposition in different positions. Therefore, in order to improve the simulation accuracy, we improved the model by considering the root superposition factor. The improved model is as following:

$$
R L D(z, r)=\sum_{i=0}^{5} R L D_{i}(z, r)=\sum_{i=0}^{5} R L D\left(z, r_{i}\right)
$$

where $r_{0}=r ; r_{1}=r_{2}=\sqrt{d^{2}+r^{2}} ; r_{3}=r_{5}=\sqrt{d^{2}+(D-r)^{2}} ; r_{4}=D-r ; d$ is plant spacing, which is $0.8 \mathrm{~m}$ in this study; $D$ is row spacing, which is $2 \mathrm{~m}$ in this study (Figure 3).

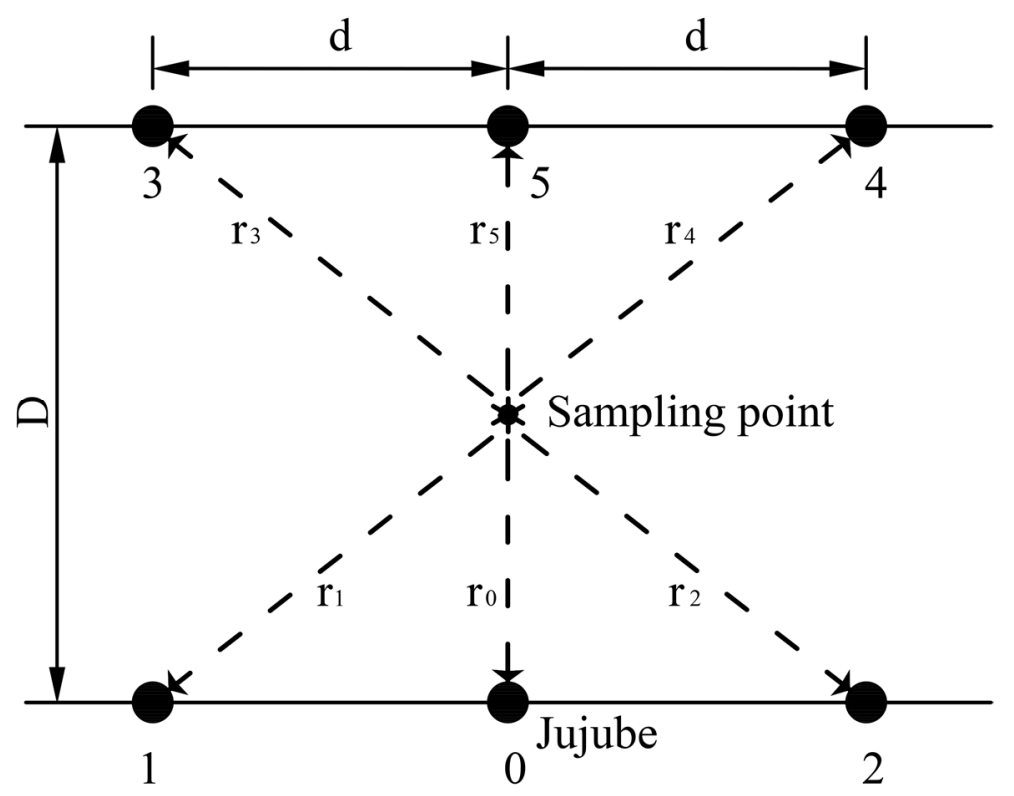

Figure 3. Schematic of jujube root two-dimensional distribution model. The abbreviations of $r_{0}, r_{1}$, $r_{2}, r_{3}, r_{4}$, and $r_{5}$ are the distance between the root of jujube tree and the sampling point. D is row spacing, $\mathrm{d}$ is plant spacing.

\subsection{Data Analysis}

Data processing and analysis of variance (ANOVA) were performed using the statistical software SPSS 17.0 (IBM Corp., Armonk, NY, USA). A Kolmogorov-Smirnov test was used to measure the frequency distributions of the dependent and independent variables. Differences between treatments were determined with the Duncan test at a significance level of 0.05. Figures were plotted using Origin 2020 (OriginLab Corp., Northampton, MA, USA). 


\section{Results}

\subsection{Soil Water Distribution}

The spatial distribution of soil water content under three drip irrigation treatments versus flood irrigation is shown in Figure 4. After one irrigation event $24 \mathrm{~h}$ (23 July 2018), the red line in the figure represents $65 \%$ of the field water holding capacity. Two-year experimental data showed that drip irrigation (W1-W3) effectively influenced soil water distribution compared to flood irrigation [9], the soil water content was significantly decreased. Moreover, there were significant differences in soil water distribution under different drip irrigation treatments (65\% field capacity as limit). The soil volume with soil moisture above $65 \%$ of the soil water holding capacity decreased with the lower irrigation water amounts.

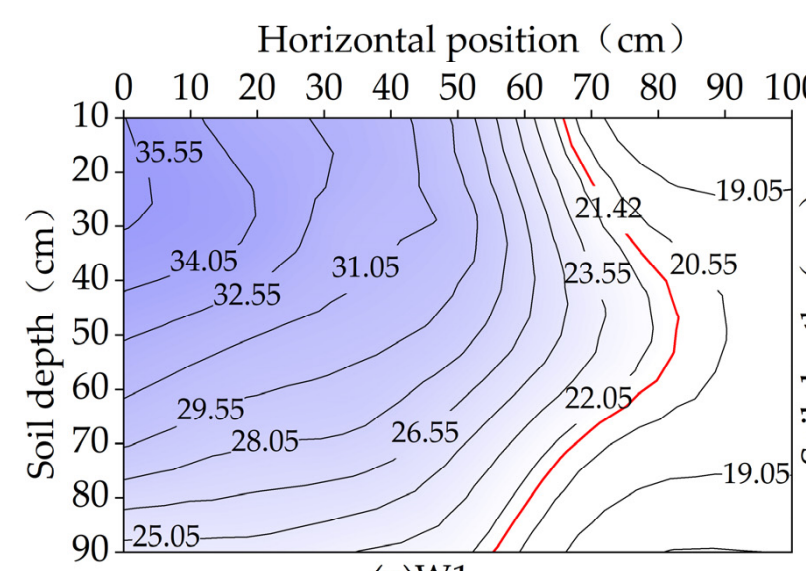

(a)W1

Horizontal position $(\mathrm{cm})$

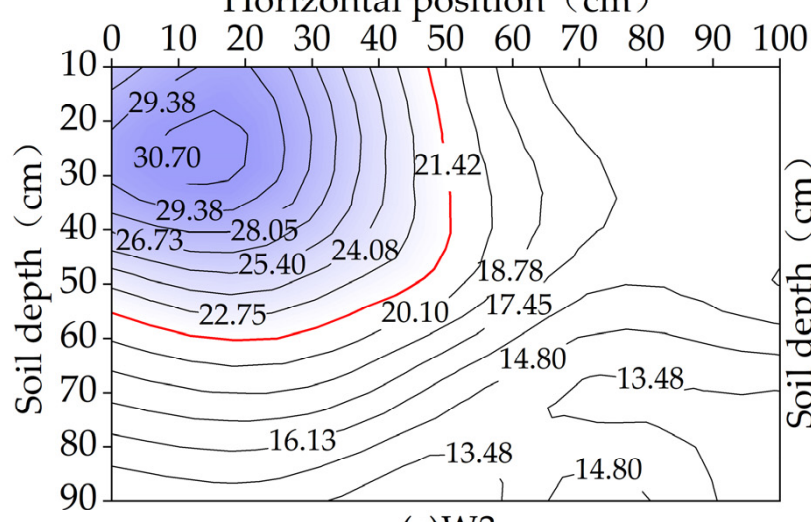

(c)W3
Horizontal position $(\mathrm{cm})$

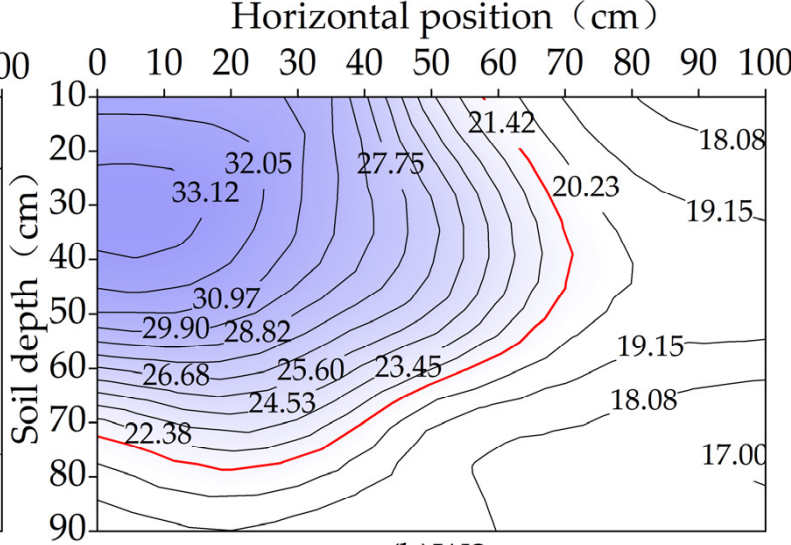

(b)W2

Horizontal position $(\mathrm{cm})$

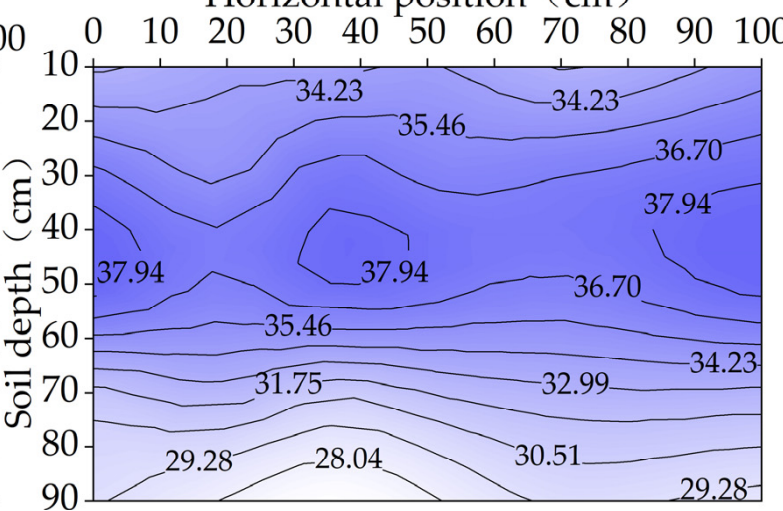

(d)CK

Figure 4. Spatial distribution of soil moisture under different irrigation treatments. The red dash line means soil moisture threshold, $65 \%$ of the average field water holding capacity of the $0-100 \mathrm{~cm}$ soil layer. W1, W2, and W3 indicate irrigation amounts of 880,660, and $440 \mathrm{~mm}$ under drip irrigation, CK indicates irrigation amount of $1100 \mathrm{~mm}$ under flood irrigation. The sampling date was 23 July 2018, after $24 \mathrm{~h}$ of one irrigation event.

\subsection{Soil Water Storage}

Figure 5 presents the change of soil water storage (SWS) in the $0-100 \mathrm{~cm}$ soil layer at different growth stages of jujube under different treatments in 2018. Compared with flood irrigation, drip irrigation (W1, W2) significantly increased the SWS of the 0-60 cm soil layer during the key growth stages of jujube trees, while it was significantly reduced in the 60-100 cm soil layer. There were significant differences in SWS under different drip irrigation treatments. SWS of the 0-60 cm depth in W1 was significantly higher in the flowering, fruit setting stage, and fruit swelling stage, while SWS in W2 was only marked higher in the fruit swelling stage. As the low irrigation amount in W3, SWS was significantly lower than other treatments during the whole growing season. 


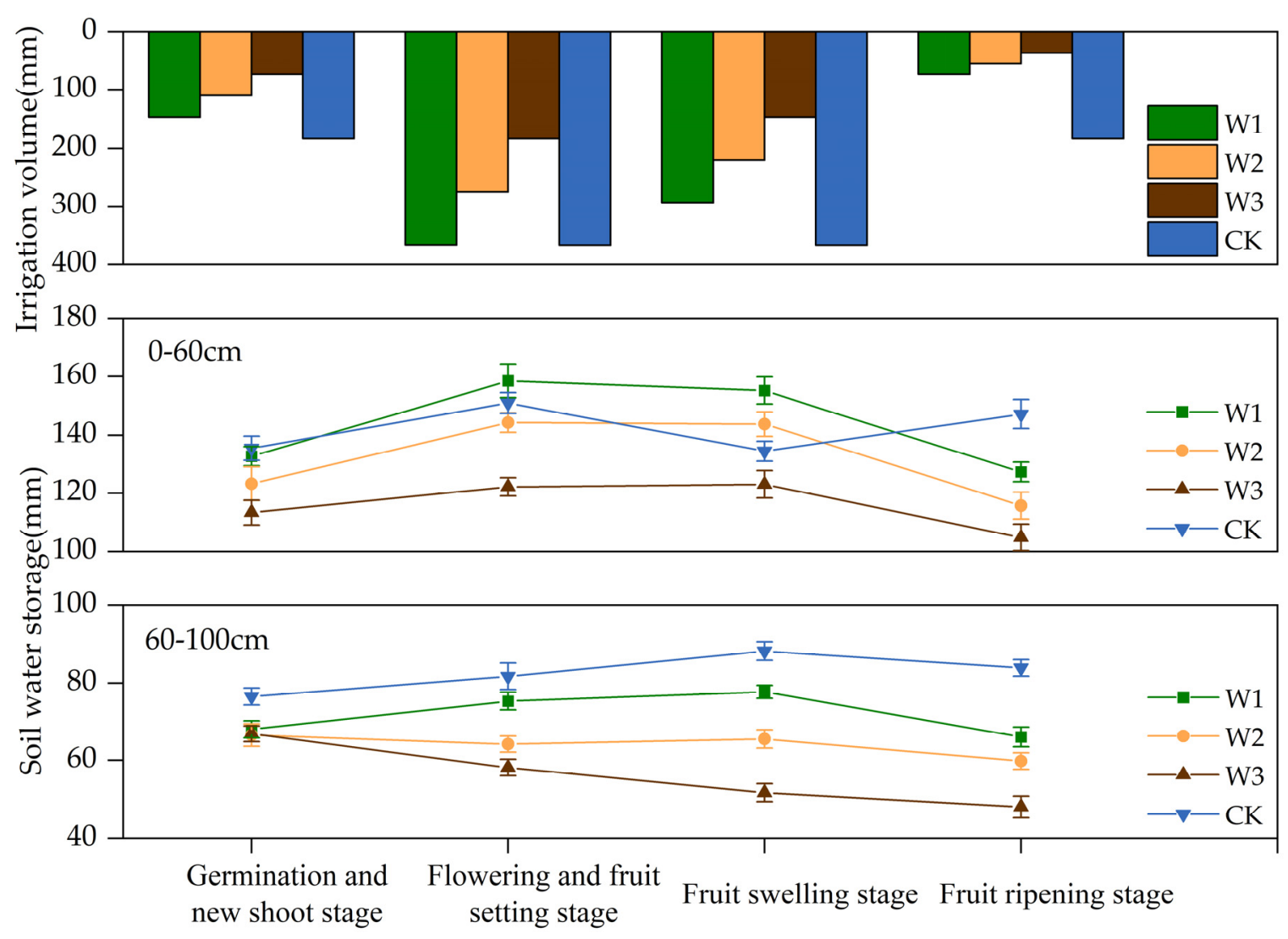

Figure 5. Soil water storage in the $0-100 \mathrm{~cm}$ soil layer at different growth stages (2018). W1, W2, and W3 indicate irrigation amounts of 880,660, and $440 \mathrm{~mm}$ under drip irrigation, CK indicates an irrigation amount of $1100 \mathrm{~mm}$ under flood irrigation. Vertical bar represents standard error.

\subsection{Root Length Density \\ 3.3.1. Vertical Distribution of RLD}

As shown in Figure 6, irrigation methods significantly changed the distribution of the roots in different soil layers. RLD was gradually decreased with the increase in soil depth in all treatments, while the decrease rate in vertical direction was different between drip irrigation and flood irrigation. After the first year of drip irrigation, the jujube roots in drip irrigation treatments (W1-W3) were mostly concentrated in the $0-60 \mathrm{~cm}$ soil layer with the maximum RLD in the $0-20 \mathrm{~cm}$ soil layer. The W1 and W2 treatments significantly changed the root length proportion and RLD at each soil layer. Compared with CK, the W1 and W2 treatments significantly increased the concentration of roots in shallow layers, but decreased in the deep layers. However, the shallow roots in W3 did not significantly differ from CK but increased the concentration of deep roots. After two-year application of drip irrigation, the W1 and W2 treatments significantly increased the mean RLD by $29.2 \%$ and $21.4 \%$ than CK in the $0-60 \mathrm{~cm}$ soil layers but decreased by $44.3 \%$ and $31 \%$ in the $60-100 \mathrm{~cm}$ soil layers. The mean RLD in W3 was $7.5 \%$ lower than that in CK in the $0-60 \mathrm{~cm}$ soil layers but increased the mean RLD by $24.5 \%$ in the $60-100$ soil layers. 


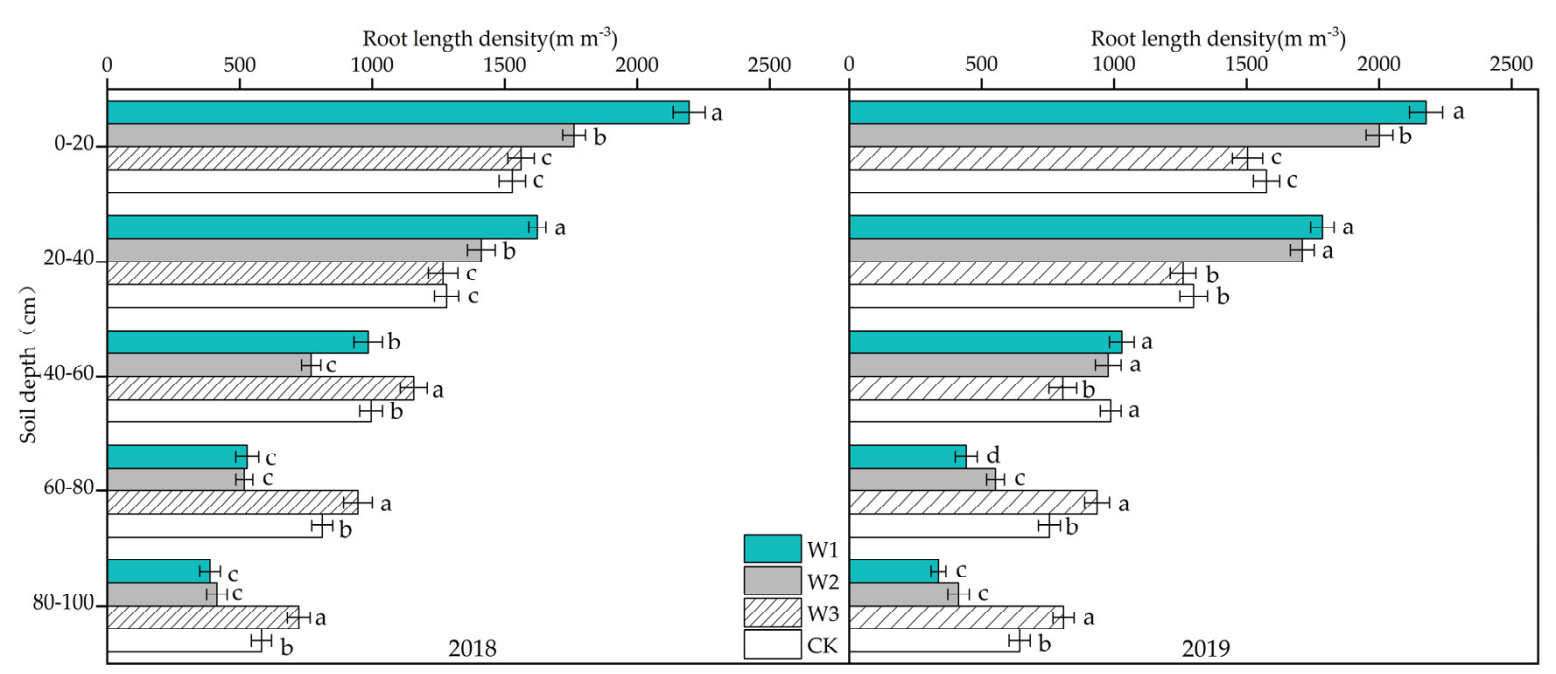

Figure 6. Vertical distribution of jujube RLD in 2018 and 2019. W1, W2, and W3 indicate irrigation amounts of 880, 660, and $440 \mathrm{~mm}$ under drip irrigation, CK indicates irrigation amount of $1100 \mathrm{~mm}$ under flood irrigation. Horizontal bar represents standard error. Different lower-case letters indicate significant differences at 0.05 level among various groups.

\subsubsection{Horizontal Distribution of RLD}

After long-term flood irrigation, the RLD of jujube trees gradually decreased with the increase in the horizontal distance, while the decrease rate was relatively small (Figure 7). After flood irrigation was replaced by drip irrigation, obvious changes occurred in the horizontal distribution of jujube root systems. In 2018 and 2019, the three drip irrigation treatments (W1-W3) all led to maximum RLD at a horizontal distance of $0-25 \mathrm{~cm}$. Drip irrigation significantly increased RLD near the drip irrigation tape and significantly decreased it farther away from the tape. Root distribution differed depending on the irrigation amount. After two-year application of drip irrigation, the jujube root system in the horizontal direction in W1 and W2 was mainly concentrated at the horizontal distance of $0-50 \mathrm{~cm}$, the mean RLD increased $39.6 \%$ and $25.8 \%$ than CK, but significantly reduced at the horizontal distance of 50-100 cm. On the contrary, the RLD in W3 showed a phenomenon that the two ends were high and the middle was low along the horizontal direction, especially at the position of $75-100 \mathrm{~cm}$ increased by $15.02 \%$ compared with CK.

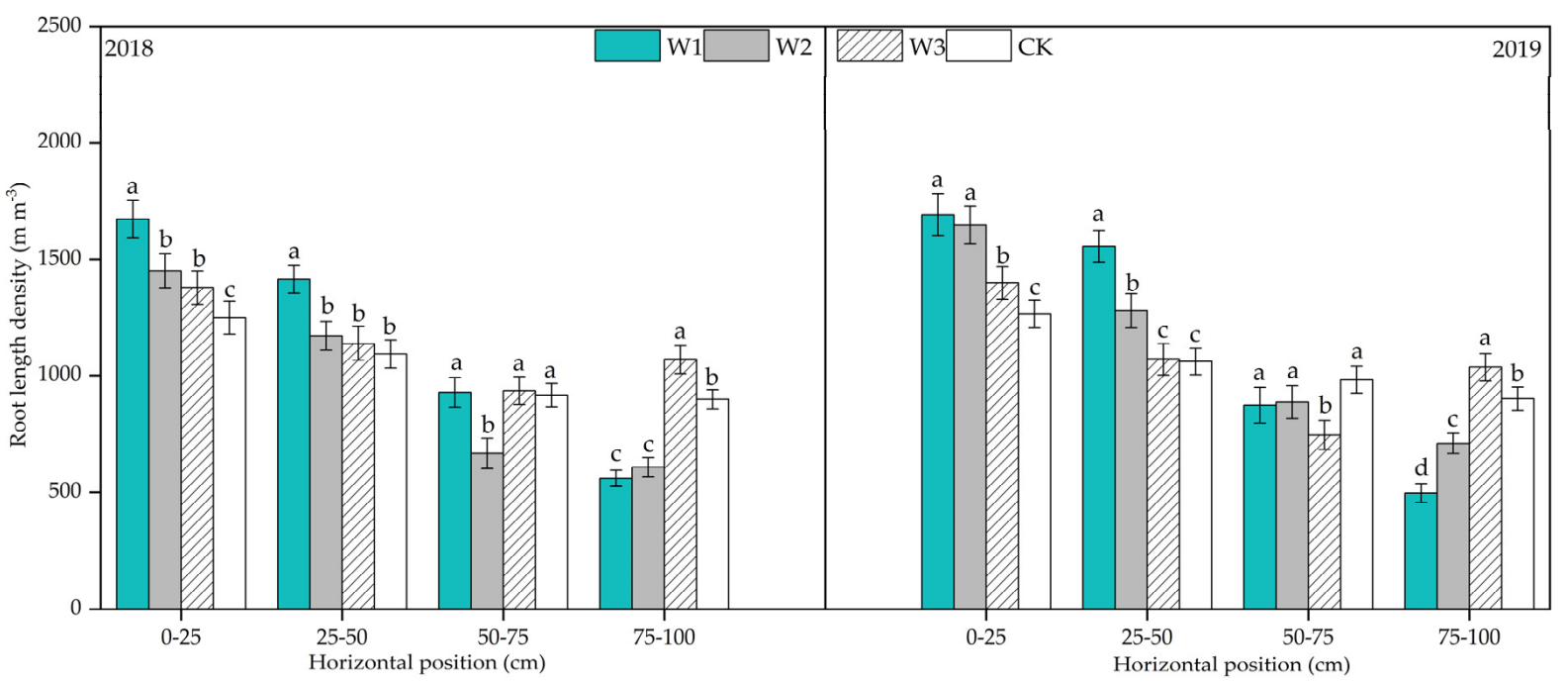

Figure 7. Horizontal distribution of jujube RLD in 2018 and 2019. W1, W2, and W3 indicate irrigation amounts of 880, 660, and $440 \mathrm{~mm}$ under drip irrigation, CK indicates irrigation amount of $1100 \mathrm{~mm}$ under flood irrigation. The horizontal bar represented standard error. Different lower-case letters indicate significant differences at 0.05 level among various groups. 


\subsubsection{RLD of Different Diameter Roots}

In the jujube orchard with long-term flood irrigation, RLD of diameter $<2 \mathrm{~mm}$ (absorption roots) was markedly greater than that with diameter $>2 \mathrm{~mm}$ (conducting roots) (Table 3). After one year of applying drip irrigation, both W1 and W2 significantly increased the RLD of jujube absorption roots in shallow soil compared with CK, but the increase rate gradually decreased as soil depth increased. There was not significant difference in RLD of absorption roots in the $0-40 \mathrm{~cm}$ soil layer between $\mathrm{W} 3$ and CK, but the difference in the soil layer of $40-100 \mathrm{~cm}$ was significant. The RLD of diameter $>2 \mathrm{~mm}$ (conductive roots) in the topsoil of W1 and W2 was significantly lower than that of CK. Jujube trees in W3 had a similar value of RLD (conducting roots) in the $0-40 \mathrm{~cm}$ soil layer compared with CK, but markedly higher than CK in the $60-80 \mathrm{~cm}$ soil layer. After two-year application of drip irrigation, the RLD of absorption roots in the 0-60 cm soil layer in W1 and W2 increased significantly compared with the value in 2018. The RLD of absorption roots in the 40-60 cm soil layer in W3 decreased markedly. In general, by replacing flood irrigation with drip irrigation, the suitable irrigation amount could effectively improve the growth of the absorbing roots and limit the growth of the conducting roots. However, an excessively low irrigation amount decreased the growth of absorbing roots in shallow soil, whereas it promoted the growth of conducting roots, which became more obvious in deep soil.

Table 3. Distribution of RLD of absorption roots $(\mathrm{d}<2 \mathrm{~mm})$ and conducting roots $(\mathrm{d}>2 \mathrm{~mm})$ of jujube in different treatments in 2018 and 2019.

\begin{tabular}{|c|c|c|c|c|c|c|c|c|c|}
\hline \multirow{2}{*}{ Year } & \multirow{2}{*}{$\begin{array}{c}\text { Soil } \\
\text { Depth } \\
\text { (cm) }\end{array}$} & \multicolumn{4}{|c|}{$\mathrm{d}<2 \mathrm{~mm}$} & \multicolumn{4}{|c|}{$\mathrm{d}>2 \mathrm{~mm}$} \\
\hline & & W1 & W2 & W3 & CK & W1 & W2 & W3 & CK \\
\hline \multirow{5}{*}{2018} & $0-20$ & $2101.6^{\mathrm{aA}}$ & $1710.7^{\mathrm{aB}}$ & $1480.9^{\mathrm{aC}}$ & $1451.4^{\mathrm{aC}}$ & $94.9^{\mathrm{aA}}$ & $51.4^{\mathrm{aC}}$ & $80.8^{\mathrm{bB}}$ & $77.7^{\mathrm{bB}}$ \\
\hline & $20-40$ & $1581.1^{\mathrm{bA}}$ & $1367.3^{\mathrm{bB}}$ & $1150.5^{b C}$ & $1162.8^{b C}$ & $42.4^{\mathrm{bB}}$ & $44.7^{\mathrm{abB}}$ & $117.1^{\mathrm{aA}}$ & $118.1^{\mathrm{aA}}$ \\
\hline & $40-60$ & $946.1^{\mathrm{cB}}$ & $731.1^{\mathrm{cC}}$ & $1111.4^{\mathrm{bA}}$ & $929.7^{c B}$ & $38.8^{\mathrm{bBC}}$ & $38.5^{\mathrm{bcBC}}$ & $45.4^{\mathrm{cB}}$ & $66.2^{b c A}$ \\
\hline & $60-80$ & $519.8^{\mathrm{dC}}$ & $500.2 \mathrm{dC}$ & $864.2^{\mathrm{cA}}$ & $760.3^{\mathrm{dB}}$ & $8.4^{\mathrm{cD}}$ & $16.9 \mathrm{dC}$ & $81.9^{\mathrm{bA}}$ & $51.2^{\mathrm{cB}}$ \\
\hline & 80-100 & $377.8^{\mathrm{eC}}$ & $404.8^{\mathrm{eC}}$ & $711.9 \mathrm{dA}$ & $568.3^{\mathrm{eB}}$ & $9.8^{\mathrm{cA}}$ & $8.9^{\mathrm{eA}}$ & $10.9^{\mathrm{dA}}$ & $13.7^{\mathrm{dA}}$ \\
\hline \multirow{5}{*}{2019} & $0-20$ & $2070.2^{\mathrm{aA}}$ & $1955.2^{\mathrm{aB}}$ & $1412.2^{\mathrm{aC}}$ & $1499.1^{\mathrm{aC}}$ & $107.1^{\mathrm{aA}}$ & $46.4^{\mathrm{aD}}$ & $91.7^{\mathrm{bB}}$ & $76.3^{\mathrm{bC}}$ \\
\hline & $20-40$ & $1737.7^{\mathrm{bA}}$ & $1662.9^{\mathrm{bA}}$ & $1149.9 \mathrm{bB}$ & $1181.7^{b B}$ & $48.8^{\mathrm{bB}}$ & $47.7^{\mathrm{aB}}$ & $110.5^{\mathrm{aA}}$ & $118.9^{\mathrm{aA}}$ \\
\hline & $40-60$ & $995.2^{\mathrm{cA}}$ & $931.1^{\mathrm{cA}}$ & $753.2^{\mathrm{deB}}$ & $918.1^{\mathrm{cA}}$ & $34.3^{\mathrm{cC}}$ & $46.8^{\mathrm{aBC}}$ & $53.4^{\mathrm{cB}}$ & $69.3^{\mathrm{bA}}$ \\
\hline & $60-80$ & $425.5^{\mathrm{dD}}$ & $521.1 \mathrm{dC}$ & $842.3^{\mathrm{cA}}$ & $707.4^{\mathrm{dB}}$ & $16.6^{\mathrm{dD}}$ & $31.4^{\mathrm{bC}}$ & $93.5^{\mathrm{bA}}$ & $48.5^{\mathrm{cB}}$ \\
\hline & 80-100 & $325.4^{\mathrm{eC}}$ & $391.3^{\mathrm{eC}}$ & $780.0^{\mathrm{cdA}}$ & $631.8^{\mathrm{edB}}$ & $11.6^{\mathrm{dB}}$ & $21.5^{\mathrm{cA}}$ & $29.2 \mathrm{dA}$ & $11.9 \mathrm{~dB}$ \\
\hline
\end{tabular}

W1, W2, and W3 indicate irrigation amounts of 880,660 , and $440 \mathrm{~mm}$ under drip irrigation, CK indicates irrigation amount of $1100 \mathrm{~mm}$ under flood irrigation. Different lower- and upper-case letters, respectively, indicate significant differences among same column and same row at 0.05 level.

\subsection{Model Application}

In Table 4 and Figure 8, we compared the measured data and simulated values of RLD using the improved model. In the treatment of W1, W2, and CK, there was a good correlation between RLD and the parameters of two-dimensional model, and the correlation coefficients were all greater than 0.8 . In the first year, transferring to drip irrigation from flooding irrigation, the determination coefficient between measured data and simulated values in W3 was 0.7 , and in the second year, the determination coefficient decreased to 0.61. Here, Pz and Pr reflect the attenuation rate of RLD along the vertical and horizontal directions, respectively. In $\mathrm{W} 1$ and $\mathrm{W} 2, \mathrm{Pz}$ and Pr were higher than that in CK, and RSME was lower than other treatments. However, Pz in W3 was lower than CK, and RMSE in W3 was significantly higher than other treatments. 
Table 4. Simulation results of jujube root two-dimensional distribution model.

\begin{tabular}{cccccc}
\hline Year & $\begin{array}{c}\text { Irrigation } \\
\text { Treatment }\end{array}$ & Pz & Pr & RMSE & $\mathbf{R}^{\mathbf{2}}$ \\
\hline \multirow{3}{*}{2018} & W1 & 3.29 & 1.40 & 0.34 & 0.94 \\
& W2 & 2.69 & 1.27 & 0.44 & 0.90 \\
& W3 & 1.19 & 0.74 & 0.84 & 0.70 \\
2019 & CK & 1.80 & 0.96 & 0.70 & 0.84 \\
\hline \multirow{3}{*}{201} & 3.38 & 1.45 & 0.42 & 0.90 \\
& W2 & 2.93 & 2.03 & 0.51 & 0.84 \\
& W3 & 1.37 & 1.53 & 0.86 & 0.61 \\
& CK & 1.98 & 1.04 & 0.71 & 0.83 \\
\hline
\end{tabular}

W1, W2, and W3 indicate irrigation amounts of 880,660 , and $440 \mathrm{~mm}$ under drip irrigation, CK indicates irrigation amount of $1100 \mathrm{~mm}$ under flood irrigation. Pz and Pr reflect the attenuation rate of root length density (RLD) along the vertical and horizontal directions, respectively. RMSE represents the root mean squared error.
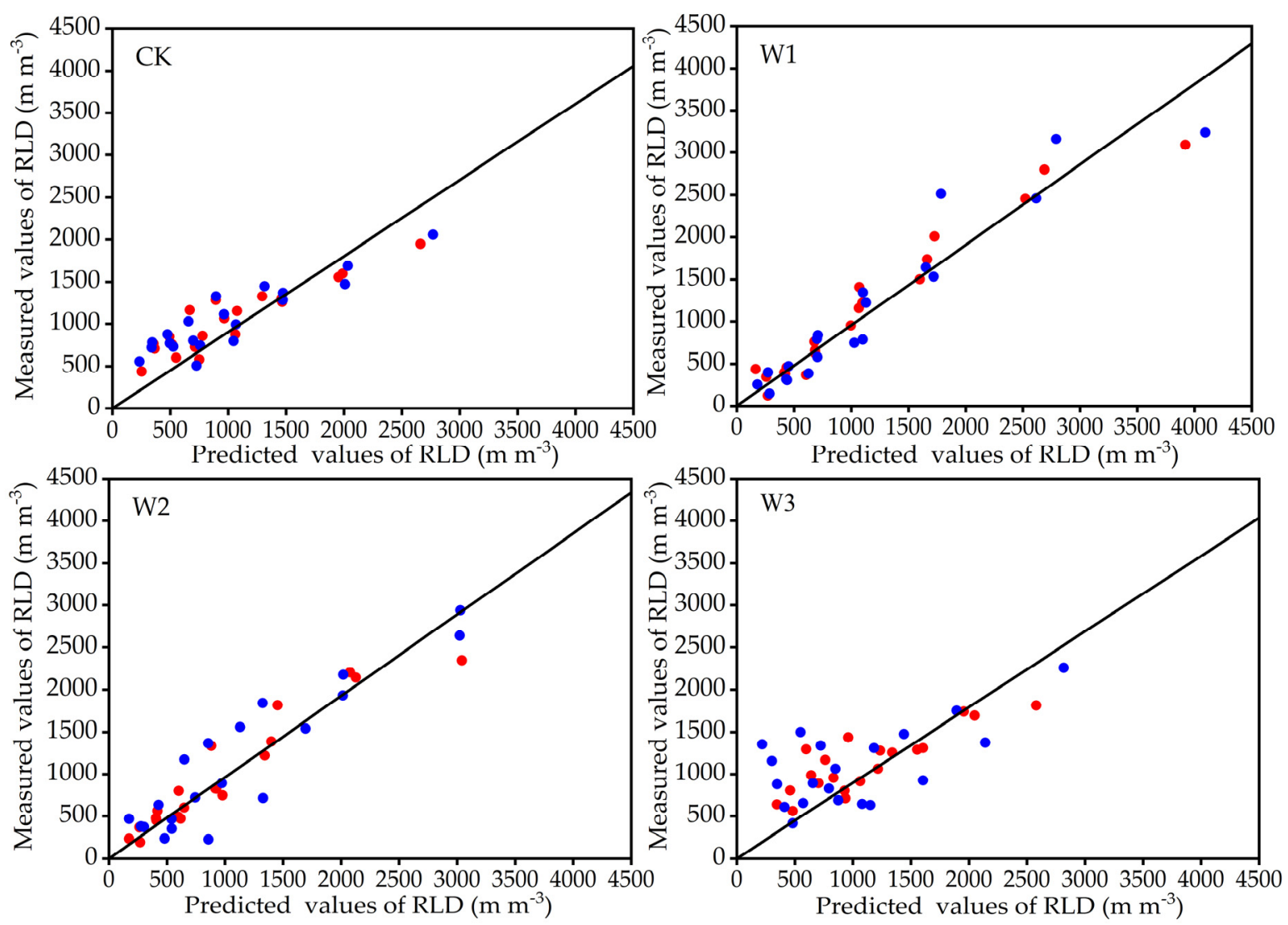

Figure 8. Relationships between measured RLD (root length density) and simulated RLD of jujube in 2018 (red dots) and 2019 (blue dots).

\subsection{Yield and WUE}

The effects of different irrigation treatments on jujube yield and WUE are shown in Table 5. Compared with flood irrigation, drip irrigation significantly decreased water consumption and improved WUE over the two years. ET of drip-irrigated jujube gradually increased with the increase in irrigation volume, while it was in reverse for WUE. After one year using drip irrigation (2018), the jujube yield in W1 in 2018 reached $8735 \mathrm{~kg} \mathrm{ha}^{-1}$ with increased yield and water use efficiency by $8.6 \%$ and $26.6 \%$, respectively, compared with CK. There was no significant difference in jujube yield between W2 and CK. After two years (2019) using drip irrigation, jujube yields in W1 and W2 were 9.91\% and 7.64\% higher than CK, respectively. The WUE of jujube under drip irrigation was $50 \%$ higher (on average) than that under CK across the two seasons. 
Table 5. Jujube fruit yield (Y), evapotranspiration (ET), and water use efficiency (WUE) in different irrigation treatments in 2018 and 2019.

\begin{tabular}{|c|c|c|c|c|}
\hline Year & Treatment & Y (kg ha $\left.{ }^{-1}\right)$ & ET (mm) & WUE $\left(\mathrm{kg} \mathrm{m}^{-3}\right)$ \\
\hline \multirow{4}{*}{2018} & W1 & $8735 \pm 259 a$ & $890.3 \pm 48.2 b$ & $98.1 \pm 3.1 c$ \\
\hline & W2 & $8297 \pm 218 b$ & $687.9 \pm 38.6 c$ & $120.6 \pm 4.2 \mathrm{~b}$ \\
\hline & W3 & $6528 \pm 176 c$ & $480.2 \pm 35.7 \mathrm{~d}$ & $135.9 \pm 4.6 \mathrm{a}$ \\
\hline & CK & $8043 \pm 279 b$ & $1037.7 \pm 53.3 \mathrm{a}$ & $77.5 \pm 1.9 \mathrm{~d}$ \\
\hline \multirow{4}{*}{2019} & $\mathrm{~W} 1$ & $8896 \pm 247 a$ & $898.3 \pm 38.6 b$ & $99.0 \pm 3.8 b$ \\
\hline & W2 & $8712 \pm 276 a$ & $694.2 \pm 31.2 c$ & $125.5 \pm 3.6 \mathrm{a}$ \\
\hline & W3 & $6022 \pm 165 c$ & $489.3 \pm 28.3 \mathrm{~d}$ & $123.1 \pm 2.9 \mathrm{a}$ \\
\hline & CK & $8094 \pm 242 b$ & $1041.3 \pm 47.6 \mathrm{a}$ & $77.7 \pm 3.2 \mathrm{c}$ \\
\hline
\end{tabular}

W1, W2, and W3 indicate irrigation amounts of 880,660 , and $440 \mathrm{~mm}$ under drip irrigation, CK indicates irrigation amount of $1100 \mathrm{~mm}$ under flood irrigation. Different lower-case letters indicate significant differences at 0.05 level among various groups.

\section{Discussion}

This study indicated that irrigation methods significantly changed soil water distribution (Figure 4). A good condition of soil water can facilitate root growth and enhance the ability of crops to absorb water and nutrients from the soil [30]. Soil water content under flood irrigation is distributed more uniformly, but it causes deep water leakage and soil evaporation [31]. Drip irrigation is a localized irrigation method, where soil water is mainly concentrated near the crop root zone, which can improve the utilization efficiency of water and fertilizers [32-34]. This study found that, under the W1 treatment, the soil water content in all soil layers within $0-50 \mathrm{~cm}$ at the horizontal direction was higher than $21.42 \%$. However, under the W3 treatment, the soil moisture content was higher than $21.42 \%$ only in the $0-60 \mathrm{~cm}$ soil layer at the horizontal distance of $0-35 \mathrm{~cm}$. The results indicate that drip irrigation can effectively impact soil moisture distribution and the scope of soil wetting area. Flood irrigation has the characteristics of a high irrigation rate and long irrigation interval, resulting in soil water content either too high or too low, which is unfavorable for the growth of plant roots [35]. We also found that the soil water content under flood irrigation was much greater than that under drip irrigation (Figure 4), but the SWS showed a large fluctuation during the growth period (Figure 5). At the jujube key growth stages, e.g., the fruit swelling stage, the soil water storage of the $0-60 \mathrm{~cm}$ soil layer in W1 and W2 was significantly higher than that in CK. It is well known that drip irrigation not only has a low irrigation rate but also has relatively short irrigation intervals. So, drip irrigation can provide a relatively good and stable soil moisture environment for jujube trees under a proper control condition.

Information of root distribution is critical for understanding soil water-nutrient cycling. Previous studies have shown that the economical yield of crops was affected by the ability of the root system to uptake water and nutrients from soil [5]. Many studies have shown that long-term irrigation management has an important impact on the distribution of fruit tree roots $[12,36,37]$. The present results showed that the spatial distribution of jujube roots was relatively stable under the condition of long-term flood irrigation (Figures 6 and 7). The density of jujube roots gradually decreased with an increase in the vertical depth and in the horizontal direction. However, the spatial variation of root distribution of jujube was small, which was consistent with soil water distribution under the flood irrigation condition. Changes in irrigation practices directly affect the soil water distribution, which in turn affects root growth and distribution $[14,38]$. After replacing flood irrigation with drip irrigation, compared with CK, both W1 and W2 increased RLD in the $0-60 \mathrm{~cm}$ soil layer and horizontally at $0-50 \mathrm{~cm}$ from the trunk, while W3 increased RLD in deep soil and at far horizontal distances. The results indicate that drip irrigation with different irrigation rates effectively regulated jujube roots development by changing soil moisture distribution. W3 with low irrigation amount significantly reduced soil water content, which resulted in the limitation of water stress on the root system. Therefore, it would stimulate the jujube roots to extend out of the soil water pattern to absorb soil 
water [39]. Song et al. [40] also found that the maximum rooting depth of apple trees was deeper in a dry year than that in a normal year in order to acquire of water by root system from deeper soil depth. This conclusion was supported by the present observation that soil water content in deep soil in W3 underwent continuous decline during the jujube growth period. Soar and Loveys [41] also reported that grapevines grown under a micro-sprinkler irrigation condition over several years showed significant changes in the development of a root system after the irrigation practice was changed to drip irrigation. However, a Brazilbased experiment reported an opposite conclusion that differences in irrigation practices did not present a significant impact on grape root systems [42]. However, the rainfall during the growing season of crops in Brazil was $512 \mathrm{~mm}$, while the rainfall in the present test area was only $50 \mathrm{~mm}$, indicating that abundant rainfall would reduce the impact of irrigation on crop root systems and could explain the discrepancies between the two different reports. Therefore, the distribution of crop root systems in arid regions with low rainfall is much more dependent on irrigation than those in regions with abundant rainfall.

Although the improved model combined the factors of crop root superposition caused by low row spacing of jujube trees, the spatial superposition degree of roots in W3 was significantly higher than that in other treatments, resulting in small determination coefficient. It was shown that, with $\mathrm{Pz}$ and $\mathrm{Pr}$, the decay rate of jujube roots was lower along the horizontal direction than the vertical direction, and the phenomenon was more obvious with increasing irrigation levels (Figure 8). The results show that the two-dimensional model could simulate the two-dimensional distribution of the root system of jujube well, but the simulation accuracy of the two-dimensional model was decreased under water stress (Table 4).

Crop yield reflects the management level of the agricultural system and soil productivity. WUE is an indicator of the relationship between crop yield and water consumption $[43,44]$. In arid regions where water resources are scarce, effective improvement of WUE while ensuring an increased or stable crop yield is essential for the sustainability of regional agriculture. As an efficient and accurate irrigation technology, drip irrigation can accurately deliver water and nutrients required by crops to the root zone, thereby improving crop yield and WUE [5,45-47]. The consecutive two-year drip irrigation experiment showed that suitable irrigation amounts can significantly improve WUE and ensure a stable increase in jujube yield (Table 5). The reason may be that the root system serves as the only channel for crops to absorb soil water and nutrients, and its growth and development directly reflect the utilization of soil resources by plants [48]. In the present experiment, the treatments of W1 and W2 significantly increased RLD of the absorbing roots, and improved matching between water distribution and root absorption, which may facilitate jujube root uptake of soil water and nutrients and increase jujube fruit yield and WUE. Plants subjected to water stress will first ensure the growth of root system, but it is unfavorable to plant growth [49]. It was also concluded from our experiment that the relatively low content of soil moisture in the topsoil in W3 did not promote the growth of absorbing roots in shallow soil layers, and the RLD of absorbing and conducting roots in deep soil were significantly increased with continuous water deficit. However, the fruit yield in W3 was minimum in the two seasons (Table 5). Huang et al. [50] considered that irrigation amounts were too low to support the crop which caused water deficit stress in the plants and had a negative impact on crop yield. Equally, excessive irrigation was also unfavorable for promoting crop yield and could reduce WUE [51], which was also confirmed by the yield and WUE of jujube in W1. Therefore, by using drip irrigation instead of flood irrigation, irrigation amount could be optimally controlled to improve soil water distribution in the root zone and regulate roots spatial distribution, which will further improve crop yield and WUE.

\section{Conclusions}

The two-year experiment showed that drip irrigation concentrated soil water distribution in a smaller range, decreased soil moisture at the $60-100 \mathrm{~cm}$ depth vertically and 
$>35 \mathrm{~cm}$ from trunk horizontally. Under drip irrigation, soil moisture and soil water storage increased with the increase in irrigation level. Drip irrigation significantly increased the RLD of jujube tree in the topsoil layer $(0-40 \mathrm{~cm})$ compared with flood irrigation. However, drip irrigation with low irrigation amounts increased the RLD in the deeper soil layer (40-100 cm). In 2019, the RLD within $50 \mathrm{~cm}$ from trunk was significantly increased under drip irrigation. Drip irrigation increased the length density of roots with a diameter $>2 \mathrm{~mm}$ at the $0-40 \mathrm{~cm}$ soil depth and decreased it in the deep soil. Compared with flood irrigation, drip irrigation effectively regulated the redistribution of roots via regulating soil water distribution. Drip irrigation significantly reduced ET over the two years, but increased yield and WUE of jujube when the irrigation level was more than $660 \mathrm{~mm}$. Accordingly, drip irrigation is an effective field-practice option to improve jujube yield and WUE in dry land.

Author Contributions: Conceptualization, Z.W. and Z.L.; Data curation, R.Z.; Formal analysis, Z.L. Funding acquisition, Z.W.; Investigation, Z.L., R.Z., T.W. and J.Z.; Software, T.W. and J.Z.; Supervision, Z.W.; writing—original draft preparation, Z.L.; writing—review and editing, Z.W. All authors have read and agreed to the published version of the manuscript.

Funding: We are grateful for the financial support from the National Natural Science Foundation of China (Grant No. 51669032) and the Innovation Team Project on the Key Fields of Xinjiang Production and Construction Corps (Grant No. 2019CB004).

Institutional Review Board Statement: Not applicable.

Informed Consent Statement: Not applicable.

Data Availability Statement: The data presented in this study are available on request from the corresponding author.

Conflicts of Interest: The authors declare no conflict of interest.

\section{References}

1. Sheng, J.; Shen, L. Chinese Jujube (Ziziphus jujuba Mill.) and Indian Jujube (Ziziphus mauritiana Lam.); Postharvest Biology and Technology of Tropical and Subtropical Fruits; Woodhead Publishing: Cambridge, MA, USA, 2011; pp. 299-326. [CrossRef]

2. Cui, N.B.; Du, T.S.; Li, F.S.; Tong, L.; Kang, S.Z.; Wang, M.X.; Liu, X.Z.; Li, Z.J. Response of vegetative growth and fruit development to regulated deficit irrigation at different growth stages of pear-jujube tree. Agric. Water Manag. 2009, 96, 1237-1246. [CrossRef]

3. Bai, T.C.; Wang, T.; Zhang, N.N.; Chen, Y.Q.; Mercatoris, B. Growth simulation and yield prediction for perennial jujube fruit tree by integrating age into the WOFOST model. J. Integr. Agric. 2020, 19, 721-734. [CrossRef]

4. Wang, H.; Li, J.; Cheng, M.; Zhang, F.; Wang, X.; Fan, J.; Wu, L.; Fang, D.; Zou, H.; Xiang, Y. Optimal drip fertigation management improves yield, quality, water and nitrogen use efficiency of greenhouse cucumber. Sci. Hortic. 2019, 243, 357-366. [CrossRef]

5. Wang, Z.; Bian, Q.; Zhang, J.; Zhou, B. Optimized water and fertilizer management of mature jujube in xinjiang arid area using drip irrigation. Water 2018, 10, 1467. [CrossRef]

6. Zhang, A.; Zheng, C.; Li, K.; Dang, H.; Cao, C.; Rahma, A.E.; Zhang, J.; Feng, D. Responses of soil water-salt variation and cotton growth to drip irrigation with saline water in the low plain near the Bohai sea. Irrig. Drain 2020, 69, 448-459. [CrossRef]

7. Yang, D.; Li, S.; Kang, S.; Du, T.; Guo, P.; Mao, X.; Tong, L.; Hao, X.; Ding, R.; Niu, J. Effect of drip irrigation on wheat evapotranspiration, soil evaporation and transpiration in Northwest China. Agric. Water Manag. 2020, 232, 106001. [CrossRef]

8. Moroke, T.S.; Schwartz, R.C.; Brown, K.W.; Juo, A.S.R. Soil water depletion and root distribution of three dryland crops. Soil Sci. Soc. Am. J. 2005, 69, 197-205. [CrossRef]

9. Liu, R.X.; Zhou, Z.G.; Guo, W.Q.; Chen, B.L.; Osterbuis, D.M. Effects of $\mathrm{N}$ fertilization on root development and activity of water-stressed cotton (Gossypium hirsutum L.) plants. Agric. Water Manag. 2008, 95, 1261-1270. [CrossRef]

10. Chen, Y.L.; Palta, J.; Clements, J.; Buirchell, B.; Siddique, K.H.M.; Rengel, Z. Root architecture alteration of narrow-leafed lupin and wheat in response to soil compaction. Field Crops Res. 2014, 165, 61-70. [CrossRef]

11. Li, P.F.; Cao, X.Q.; Tan, H.; Wang, J.H.; Ren, S.M.; Yang, P.L. Studies on water uptake and heat status of cherry root under water-saving measures. Agric. Water Manag. 2020, 242, 106359. [CrossRef]

12. Ruiz-Sanchez, M.C.; Plana, V.; Ortuno, M.F.; Tapia, L.M.; Abrisqueta, J.M. Spatial root distribution of apricot trees in different soil tillage practices. Plant Soil. 2005, 272, 211-221. [CrossRef]

13. Forde, B.; Lorenzo, H. The nutritional control of root development. Plant Soil. 2001, 232, 51-68. [CrossRef] 
14. Fernandes, R.D.M.; Egea, G.; Hernandez-Santana, V.; Diaz-Espejo, A.; Fernandez, J.E.; Perez-Martin, A.; Cuevas, M.V. Response of vegetative and fruit growth to the soil volume wetted by irrigation in a super-high-density olive orchard. Agric. Water Manag. 2021, 258, 107197. [CrossRef]

15. Cao, X.C.; Wu, L.L.; Lu, R.H.; Zhu, L.F.; Zhang, J.H.; Jin, Q.Y. Irrigation and fertilization management to optimize rice yield, water productivity and nitrogen recovery efficiency. Irrig. Sci. 2021, 39, 235-249. [CrossRef]

16. Watson, W.T.; Appel, D.N.; Arnold, M.A.; Kenerley, C.M. Spatial distribution of Malus root systems in irrigated, trellised orchards. J. Hortic. Sci. Biotechnol. 2006, 81, 745-753. [CrossRef]

17. Kadyampakeni, D.M.; Morgan, K.T.; Schumann, A.W.; Nkedi-Kizza, P. Effect of irrigation pattern and timing on root density of young citrus trees infected with Huanglongbing disease. Horttechnology 2014, 24, 209-221. [CrossRef]

18. Chilundo, M.; Joel, A.; Wesstrom, I.; Brito, R.; Messing, I. Response of maize root growth to irrigation and nitrogen management strategies in semi-arid loamy sandy soil. Field Crops Res. 2017, 200, 143-162. [CrossRef]

19. Li, X.; Tian, D.; Guo, K.; Xu, B.; Zhao, S. Influence of mulch drip irrigation on wheat root distribution characteristics. Irrig. Mach. Eng. 2016, 34, 545-552. [CrossRef]

20. Ma, L.H.; Liu, X.L.; Wang, Y.K.; Wu, P.T. Effects of drip irrigation on deep root distribution, rooting depth, and soil water profile of jujube in a semiarid region. Plant Soil. 2013, 373, 995-1006. [CrossRef]

21. Salgado, E.; Cautin, R. Avocado root distribution in fine and coarse-textured soils under drip and microsprinkler irrigation. Agric. Water Manag. 2008, 95, 817-824. [CrossRef]

22. Ma, L.H.; Wu, P.T.; Wang, X. Root distribution chrono sequence of a dense dwarfed jujube plantation in the semiarid hilly region of the Chinese Loess Plateau. J. Forest Res. 2014, 19, 62-69. [CrossRef]

23. Bai, T.; Zhang, N.; Wang, T.; Wang, D.; Yu, C.; Meng, W.; Fei, H.; Chen, R.; Li, Y.; Zhou, B. Simulating on the effects of irrigation on jujube tree growth, evapotranspiration and water use based on crop growth model. Agric. Water Manag. 2021, $243,106517$. [CrossRef]

24. Wang, C.; Bai, D.; Li, Y.; Yao, B.; Feng, Y. The comparison of different irrigation methods on yield and water use efficiency of the jujube. Agric. Water Manag. 2021, 252, 106875. [CrossRef]

25. Liu, X.L.; Ma, L.H.; Wang, Y.K. Distribution characteristic of fine root and soil water of densely jujube plantation with drip irrigation. Trans. Chin. Soc. Agric. Eng. 2013, 29, 63-71.

26. Zhang, J.F.; Geng, Q.L.; Cao, W.C.; Chen, Q.; Chang, R.X.; Liang, Z.; Chen, S.H. Effects of type and amount of nitrogen fertilizer on photosynthetic characteristics and yield of jujube under drip irrigation. Trans. Chin. Soc. Agric. Eng. 2020, 36, 92-98.

27. Li, F.Y.; Lao, D.Q.; Sun, S.M.; Yao, B.L.; Sun, L.D. Effects of drip irrigation on photosynthetic characteristics and water use efficiency of jujube-cotton intercropping system. Trans. Chin. Soc. Agric. Mach. 2016, 47, 119-129.

28. Zhang, H. Simulation of Water Transmission for Transplanted Cotton following Wheat under Different Irrigation Methods. Ph.D Thesis, Chinese Academy of Agricultural Sciences, Beijing, China, 2017; pp. 65-70. (In Chinese).

29. Vrugt, J.A.; Hopmans, J.W.; Simunek, J. Calibration of a two-dimensional root water uptake model. Soil Sci. Soc. Am. J. 2001, 65, 1027-1037. [CrossRef]

30. Hu, Y.J.; Ma, P.H.; Wu, S.F.; Sun, B.H.; Feng, H.; Pan, X.L.; Zhang, B.B.; Chen, G.J.; Duan, C.X.; Lei, Q.; et al. Spatial-temporal distribution of winter wheat (Triticum aestivum L.) roots and water use efficiency under ridge-furrow dual mulching. Agric. Water Manag. 2020, 240, 106301. [CrossRef]

31. Lu, W.H.; Ren, A.T.; Yang, J.J.; Yu, L.; Ma, C.H.; Zhang, Q.B. Soil water and salt movement and spatial distribution of fine alfalfa roots under drip irrigation. Trans. Chin. Soc. Agric. Eng. 2014, 30, 128-137. [CrossRef]

32. Batchelor, C.; Lovell, C.; Murata, M. Simple microirrigation techniques for improving irrigation efficiency on vegetable gardens. Agric. Water Manag. 1996, 32, 37-48. [CrossRef]

33. Ayars, J.E.; Phene, C.J.; Hutmacher, R.B.; Davis, K.R.; Schoneman, R.A.; Vail, S.S.; Mead, R.M. Subsurface drip irrigation of row crops: A review of 15 years of research at the Water Management Research Laboratory. Agric. Water Manag. 1999, 42, 1-27. [CrossRef]

34. Wang, Z.; Jin, M.; Simunek, J.; van Genuchten, M.T. Evaluation of mulched drip irrigation for cotton in arid Northwest China. Irrig. Sci. 2014, 32, 15-27. [CrossRef]

35. Suralta, R.R.; Yamauchi, A. Root growth, aerenchyma development, and oxygen transport in rice genotypes subjected to drought and waterlogging. Environ. Exp. Bot. 2008, 64, 75-82. [CrossRef]

36. Fernández, J.E.; Moreno, F.; Cabrera, F.; Arrue, J.L.; Martín-Aranda, J. Drip irrigation, soil characteristics and the root distribution and root activity of olive trees. Plant Soil. 1991, 133, 239-251. [CrossRef]

37. Stevens, R.M.; Douglas, T. Distribution of grapevine roots and salt under drip and full-ground cover microjet irrigation systems. Irrig. Sci. 1994, 15, 147-152. [CrossRef]

38. Wu, Y.; Wang, W.; Huang, X.; Ren, D.; Su, L.; Liu, Z. Yield and root growth of mature Korla fragrant pear tree under deficit irrigation. Trans. Chin. Soc. Agric. Eng. 2012, 43, 78-84. [CrossRef]

39. Wu, Y.; Zhao, Z.; Wang, W.; Huang, X.; Ma, Y. Effect of regulated deficit irrigation and irrigation mode on fine roots redistribution of fragrant pear trees. Trans. Chin. Soc. Agric. Mach. 2017, 48, 244-250. [CrossRef]

40. Song, X.; Gao, X.; Wu, P.; Zhao, X.; Zhang, W.; Zou, Y.; Siddique, K.H.M. Drought responses of profile plant-available water and fine-root distributions in apple (Malus pumila Mill.) orchards in a loessial, semi-arid, hilly area of China. Sci. Total Environ. 2020, 723, 137739. [CrossRef] 
41. Soar, C.J.; Loveys, B.R. The effect of changing patterns in soil-moisture availability on grapevine root distribution, and viticultural implications for converting full-cover irrigation into a point-source irrigation system. Aust. J. Grape Wine Res. 2007, 13, 2-13. [CrossRef]

42. Bassoi, L.H.; Hopmans, J.W.; Jorge, L.A.D.C.; Alencar, C.M.D.; Silva, J.A.M.E. Grapevine root distribution in drip and microsprinkler irrigation (Distribuição radicular de videiras irrigadas por gotejamento e microaspersão). Sci. Agric. 2003, 60, 377-387. [CrossRef]

43. Du, T.; Kang, S.; Zhang, J.; Li, F. Water use and yield responses of cotton to alternate partial root-zone drip irrigation in the arid area of north-west China. Irrig. Sci. 2008, 26, 147-159. [CrossRef]

44. Mukherjee, A.; Kundu, M.; Sarkar, S. Role of irrigation and mulch on yield, evapotranspiration rate and water use pattern of tomato (Lycopersicon esculentum L). Agric. Water Manag. 2010, 98, 182-189. [CrossRef]

45. Wang, D.; Kang, Y.; Wan, S. Effect of soil matric potential on tomato yield and water use under drip irrigation condition. Agric. Water Manag. 2007, 87, 180-186. [CrossRef]

46. Kiani, M.; Gheysari, M.; Mostafazadeh-Fard, B.; Majidi, M.M.; Karchani, K.; Hoogenboom, G. Effect of the interaction of water and nitrogen on sunflower under drip irrigation in an arid region. Agric. Water Manag. 2016, 171, 162-172. [CrossRef]

47. Si, Z.Y.; Zain, M.; Mehmood, F.; Wang, G.S.; Gao, Y.; Duan, A.W. Effects of nitrogen application rate and irrigation regime on growth, yield, and water-nitrogen use efficiency of drip-irrigated winter wheat in the North China Plain. Agric. Water Manag. 2020, 231, 106002. [CrossRef]

48. Luo, H.H.; Zhang, H.Z.; Zhang, Y.L.; Zhang, W.F. Effects of water storage in deeper soil layers on the root growth, root distribution and economic yield of cotton in arid area with drip irrigation under mulch. J. Appl. Ecol. 2012, 23, 395-402. [CrossRef]

49. Romero, P.; Botia, P.; Garcia, F. Effects of regulated deficit irrigation under subsurface drip irrigation conditions on vegetative development and yield of mature almond trees. Plant Soil. 2004, 260, 169-181. [CrossRef]

50. Huang, B.R.; Fry, J.D. Root anatomical, physiological, and morphological responses to drought stress for tall fescue cultivars. Crop Sci. 1998, 38, 1017-1022. [CrossRef]

51. Li, B.; Sun, J.; Wei, X.; Zheng, S.; Ge, D.; Fu, S. Effects of lower limit of drip irrigation on growth, yield and root distribution of greenhouse grapes. Sci. Agric. Sin. 2020, 53, 1432-1443. [CrossRef] 